Dmytrovych, Chornobuk Valery Ivanovych regarding the constitutionality of the provisions of part five of Article 176 of the Criminal Procedure Code of Ukraine]: https://zakon.rada.gov.ua/laws/show/v007p710-19\#n40 (in Ukrainian)

64. O vosstanovlenii prav vsekh zhertv politicheskih repressij 20-50-h godov. Ukaz Prezidenta Soyuza Sovetskih Socialisticheskih Respublik ot 13 avgusta $1990 \mathrm{~g}$. Izvestiya. [On restoring the rights of all victims of political repression in the 1920s and 1950s] 1990. №227. (in Russian))

65. Pro ratifikaciyu Mizhnarodnogo paktu pro ekonomichni, social'ni i kul'turni prava ta Mizhnarodnogo paktu pro gromadyans'ki i politichni prava. Ukaz Prezidiï Verhovnoï Radi Ukraïns'koï RSR vid 19 zhovtnya 1973 roku. [On ratification of the International Covenant on Economic, Social and Cultural Rights and the International Covenant on Civil and Political Rights]: https://zakon.rada.gov.ua/laws/show/2148-08\#Text (in Ukrainian)
66. Ustav ugolovnogo sudoproizvodstva. Izdanie 1892 goda. [Charter of criminal proceedings]: https://constitution.garant.ru/history/act1600-1918/ $3137 /$ (in Russian)

67. Hronologichne zibrannya zakoniv, ukaziv Prezidiï Verhovnoï Radi, postanov i rozporyadzhen' Uryadu Ukraïns'koï RSR(1917-1941rr.). [Chronological collection of laws, decrees of the Presidium of the Verkhovna Rada, resolutions and orders of the Government of the Ukrainian SSR (19171941).] T.1. K., 1963. S. 555 (in Russian)

68. CDAVOU . F. 1115.[ TsDAVO] Ukraïns'ka Central'na Rada. Op. 1. Odn. zb. 1. Ark.S. 169-170 (in Ukrainian)

Received: $31 / 07 / 2021$ Accepted: $20 / 08 / 2021$

V. Shybiko, Cand. Sc. (Law), Prof.

Taras Shevchenko National University of Kyiv, Kyiv, Ukraine

\title{
EVOLUTION OF CRIMINAL PROCEDURE OF UKRAINE WITHIN THE PERIOD OF 30 YEARS OF UKRAINIAN INDEPENDENCE
}

In the article, the author explores relevant issues of the formation and development of the Ukrainian criminal process over the 30 years of existence of the state of Ukraine since the proclamation of its independence.

The main stages of the development of the criminal procedure are highlighted and analysed in detail, namely: the stage of its formation since Ukraine's independence proclamation in 1990-1991; the stage of development of the criminal procedure after Ukraine's accession to the Council of Europe and the adoption of the new Constitution of 1996; the stage of the criminal procedure development after the adoption of the new Criminal Procedure Code (CrPC) of Ukraine in 2012. The novelties of the CrPC of 2012 are comprehensively analysed. Firstly, the Code incorporated the relevant key provisions of the Constitution of Ukraine and international legal acts on human rights and justice. Secondly, it settled a number of issues that were important for criminal proceedings but were either unregulated or partially regulated by other laws or regulations.

The article provides an analysis of the principle of access to justice enshrined in the CrPC of 2012, which provides for the right of participants in criminal proceedings who have a vested interest in the results of these proceedings (suspect, accused, victim), not only to obtain a fair trial but also to use broad procedural rights and to take an active part in criminal proceedings both during the pre-trial investigation and during the trial, contributing to the comprehensive, complete, and impartial establishment of the circumstances of the criminal proceedings and the adoption of a fair trial.

The author also touches on the amendments to the CrPC of 2012, which are related to the military aggression of the Russian Federation against Ukraine and the impossibility of pre-trial investigation and trial in the areas of the anti-terrorist operation, as well as those related to the implementation of the UN Convention against Corruption, aimed at strengthening the fight against corruption crimes.

Keywords: criminal procedure, independence of Ukraine, Ukrainian CrPC of 2012, human rights, judicial control, access to justice, special criminal proceedings (in absentia), waiver of obligations under the ECHR, criminal proceedings of corruption crimes.

Bulletin of Taras Shevchenko National University of Kyiv. Legal Studies, 2021; 3 (118): 142-147

УДК 341.1/8

DOI: https:doi.org/10.17721/1728-2195/2021/3.118-24
ISSN 1728-2195

(C) Taras Shevchenko National University of Kyiv, Publishing center "Kyiv University", 2021

Х. Ю. Ямельська, асп.
Київський національний університет імені Тараса Шевченка, Київ, Україна ORCID ID: 0000-0001-6121-7308

\section{ЗАПОБІГАННЯ КАТУВАННЮ НА ТИМЧАСОВО ОКУПОВАНИХ ТЕРИТОРІЯХ УКРАЇНИ}

Розкрито зміст збройної агресії та правовий статус тимчасово окупованих територій України. Розглянуто агресію Росії щодо України в історичній ретроспективі. На конкретних випадках продемонстровано випадки катування й інших видів неналежного поводження на тимчасово окупованих територіях. Розглянуто стан дотримання прав людини на тимчасово окупованих територіях, а саме запобігання катуванню й іншим видам неналежного поводження. Визначено шляхи запобігання катуванню та неналежному поводженню з метою дотримання прав людини та збереження правового порядку.

Визначено, що система протидії агресії Росії, яка полягає у застосуванні політичних, юридичних та економічних засобів, включає в себе запобігання катуванню та жорстокому поводженню. Зазначено, що прийняття резолюцій ГА ООН щодо територіальної цілісності, ситуації з правами людини в АР Крим та місті Севастополь та іниих документів КМРє, ПАРє, ОБСє є новим елементом дедалі більшого правового тиску на Росію та елементом запобігання катуванням. Провадження в ЄСПЛ за скаргами України проти Росії визначаються одним з ефективних засобів запобігання катуванням. Розкрито вплив експертної й адвокаційної діяльності неурядових правозахисних організацій на запобігання катуванням і стан дотримання прав людини на тимчасово окупованих територіях. Зазначено, що підтримування 36'язків із громадянами АР Крим, постійне інформування, а також отримання українською стороною інформації стосовно стану дотримання прав людини на тимчасово окупованій території дає можливість для часткового запобігання таким порушенням, а також уможливлює майбутню реінтеграцію цих територій.

Ключові слова: запобігання катуванню, тимчасово окуповані території, збройна агресія, дотримання прав людини.

\section{ВСТУП}

Збройна агресія Росії щодо України створила катастрофічні наслідки у вигляді зруйнованих людських життів, підірваної економіки, руйнування всіх можливих демократичних інститутів. Постійний режим окупації відбувається із численними порушеннями не тільки міжнародного, а й гуманітарного права. Усе це створює безпрецедентні умови для свавілля незаконних військових угруповань на Сході України та збройних сил Росії на території Криму, що проявляються у скоєнні найтяжчих злочинів проти людства та людяності. У таких умовах вкрай важко, а подекуди й неможливо запобігати катуванню та жорсткому поводженню. Протягом усього часу збройної агресії та окупації територій
України безперервно фріксуються найважчі злочини, зокрема катування та інші види неналежного поводження. Запобігти катуванню у таких умовах майже неможливо, однак це не означає, що робота міжнародних правозахисних організацій, міжнародних місій має бути припинена. Навпаки, напрацювання, здійснені вищезазначеними органами, створюють доказову базу для захисту прав потерпілих у національних і міжнародних судах.

Метою статті $€$ визначення шляхів запобігання катуванню та неналежному поводженню на тимчасово окупованих територіях. 


\section{ВИКЛАД ОСНОВНОГО МАТЕРІАЛУ}

Зважаючи на продовження збройної агресії Росії проти України, режиму окупації, мілітаризацію тимчасово окупованих територій, повторюваність випадків катування та неналежного поводження на тимчасово окупованих територіях, дослідження запобігання катуванню та неналежному поводженню $€$ актуальним, оскільки дасть змогу вирізнити найбільш ефективні шляхи для запобігання катуванню та неналежному поводженню.

Серед учених питання визначення правового статусу тимчасово окупованих територій України, порушення прав людини на цих територіях досліджували О. Задорожній, М. Гнатовський, А. Кориневич, В. Човган.

Спланована збройна агресія Росії проти України розпочалася 20 лютого 2014 року з військової операції збройних сил РФ із захоплення частини території України - Кримського півострова. Агресивна війна Російської Федерації проти України не тільки забрала життя тисяч людей, змусила людей залишати свої домівки, зруйнувала економічний і господарський комплекси регіонів України, знищила інститут захисту прав людини, а й фактично загрожує всьому мирному світовому та регіональному європейському порядку, який базується на таких принципах міжнародного права, як незастосування сили чи погрози силою, мирного розв'язання міжнародних спорів, територіальної цілісності, поваги прав і свобод людини, добросовісного виконання міжнародних зобов'язань.

Застосування Російською Федерацією сили проти України на Кримському півострові не відповідає жодній із вимог, які міжнародне право висуває для визнання застосування державою сили правомірним. Зіставлення фрактичних дій Росії з нормами міжнародного права свідчить про порушення нею практично всіх обов'язків держави, пов'язаних із повагою до територіальної цілісності інших держав. Відбулось протиправне захоплення Росією із застосуванням власних збройних сил частини України, тобто насильницьке приєднання території іншої держави, яке відповідно до міжнародного права може бути визначене лише як анексія. Отже йдеться про військову агресію Російської Федерації, спрямовану на анексію Кримського півострова [1, с. 416].

Наступним етапом російської агресії стала спроба дестабілізувати ситуацію у східних і південних регіонах України з метою утворення на цій території квазідержави "Новоросія". Ці плани були оприлюднені російським президентом В. Путіним у ході телевізійної програми "Діалог із росіянами" на Першому каналі 17 квітня 2014 року. Повній реалізації цих планів вдалося перешкодити, але російські регулярні війська та керовані РФ незаконні збройні формування окупували окремі райони Донецької та Луганської областей України [2].

О. Задорожній зазначив, що бойові дії підрозділів російської армії проти Збройних сил України потрібно кваліфікувати як агресію. Дії Російської Федерації проти нашої держави порушують норми міжнародного права, їх можна розцінювати лише як військову агресію в розумінні ухваленої на 29-й сесії Генеральної Асамблеї ООН 1974 р. Резолюції "Визначення агресії" та змін 2010 р. до Статуту Міжнародного кримінального суду 1998 р. - застосування збройної сили державою проти суверенітету, територіальної недоторканності або політичної незалежності іншої держави. У 2014-2015рр. Російська Федерація вчинила практично всі види агресії, передбачені цими актами, ведучи проти нашої держави агресивну війну [3, с. 115].

Крім того, країни Заходу застосували політичні й економічні санкції проти держави-агресора, що виявились дуже дієвими у протистоянні агресії Росії. Вони дозволили пригальмувати російську агресію проти України, знизити ймовірність широкомасштабного вторгнення та примусили РФ, сісти за стіл переговорів, зокрема в межах Тристоронньої контактній групи (сторони конфллікту - Україна та РФ, а також ОБСє як посередник) та Нормандської четвірки (сторони конфлікту Україна та РФ, посередники - Франція та ФРН) [2].

Завдяки героїзму та мужності українського народу активну збройну агресію Росії проти України вдалося зупинити. Однак унаслідок збройної агресії частина території України та територія Автономної Республіки Крим була тимчасово окупована.

Відповідно до теорії міжнародного права режим окупації $€$ інститутом міжнародного гуманітарного права, який виникає під час або внаслідок агресії чи збройних конфліктів, регулюється Гаазькою конвенцією про закони і звичаї сухопутної війни 1907 року [4], Женевською конвенцією про захист цивільного населення під час війни 1949 р. [5], Гаазькою конвенцію про захист культурних цінностей на випадок збройного конфллікту 1954 р. [6].

Відповідно до ст. 42 Гаазької конвенції про закони і звичаї сухопутної війни територія визнається окупованою, якщо вона фрактично перебуває під владою армії супротивника. Окупація поширюється лише на ту територію, де така влада встановлена і здатна виконувати свої функції [4].

Відповідно до ст. 3 Закону України "Про забезпечення прав і свобод громадян і правовий режим на тимчасово окупованій території України" від 15 квітня 2014 р. № 1207-VII тимчасово окупованою територією визначається сухопутна територія Автономної Республіки Крим та міста Севастополя, внутрішні води України цих територій; внутрішні морські води і територіальне море України навколо Кримського півострова, територія виключної (морської) економічної зони України вздовж узбережжя Кримського півострова та прилеглого до узбережжя континентального шельфу України, на які поширюється юрисдикція органів державної влади України відповідно до норм міжнародного права, Конституції та законів України; надра під територіями, зазначеними у п. 1 і 2 цієї частини, і повітряний простір над цими територіями [7]

Варто додати, що окупація $є$ тимчасовим явищем i не передбачає переходу суверенітету або правового титулу на окуповану територію до держави-окупанта. Таким чином, окупація Російською Федерацією території Автономної Республіки Крим і міста Севастополь із погляду міжнародного права $є$ тимчасовою і не означає, що Російська Федерація має суверенітет над цими територіями. Навпаки, з погляду міжнародного права, саме Україна $€$ сувереном цих територій і вони $€$ ії невід'ємними складовими [8, с. 617].

Кваліфікувати ситуацію в деяких районах Донецької і Луганської областей, які не контролюються українською владою, з погляду визначення наявності режиму окупації складніше. Оскільки для того, щоб вважати Російську федерацію окупантом цих територій потрібно доводити, що ці території перебувають під владою і контролем саме збройних сил Російської Федерації, а не організованих антиурядових збройних формувань так званих "Донецької народної республіки" і "Луганської народної республіки" [8, с. 618].

2014 р. прийнято Закон України "Про особливий порядок місцевого самоврядування в окремих районах Донецької та Луганської областей" [9]. Нормативноправовим актом визначається тимчасовий, строком на три роки, порядок організації місцевого самоврядування, діяльності органів місцевого самоврядування в окремих районах Донецької та Луганської областей, до яких належать райони, міста, селища, села. 
Фактично територія Донецької та Луганської областей АР Крим нині не є підконтрольною Україні.

Найболісніший аспект агресії Росії у Криму - грубі, систематичні, масові порушення цією державою прав людини на півострові [1, с. 418] Агресія Російської Федерації у Луганській і Донецькій областях, що сама по собі становить серйозне порушення основних принципів міжнародного права, супроводжується брутальними, системними, масовими порушеннями основних прав людини [8, с. 605].

3 моменту окупації територій Донецької та Луганської областей АР Крим 2014 року і донині там фріксуються масові порушення прав людини і основоположних свобод щодо життя, свободи, безпеки, особистої недоторканності.

У квітні 2014 року у Слов'янську озброєні терористи розстрілювали людей "упритул", було знайдено тіла двох закатованих людей, одним з яких був депутат Горлівської міськради В. Рибак, якого напередодні викрали терористи. 26 травня у Донецьку взято в заручники дві групи спостерігачів ОБСЄ. Amnesty International зазначали про викрадення цивільного населення заради викупу, обміну, піддавання їх тортурам або вбивству [8, с. 606].

Порушення прав людини на території АР Крим здійснюється за підтримки та схвалення вищого керівництва Російської Федерації. Так, "Крим SOS" створила інтерактивну мапу правопорушень у Криму відповідно до повідомлень у ЗМІ та звітів міжнародних і національних правозахисних організацій. Станом на грудень 2016 року зафріксовано 269 правопорушень, більшість з яких є порушенням прав на життя, свободу, безпеку й особисту недоторканність. Серед резонансних випадків варто згадати справу українського кінорежисера О. Сенцова, якого разом із проукраїнськими активістами О. Кольченком та О. Чернієм ФСБ РФ затримало 10 травня 2014 року. У лютому 2015 року в Криму був затриманий, а в подальшому підданий тортурам, заарештований, притягнений до кримінальної відповідальності та засуджений до 4,2 років позбавлення волі проукраїнський активіст громадянин України О. Костенко [10].

Протягом 2014-2016 р. дії Російської Федерації були спрямовані на ліквідацію політичної та інтелектуальної еліти кримськотатарського народу та провокування внутрішнього розколу шляхом підкупу, залякувань, у тому числі фізичного знищення. Зокрема, 3 травня 2014 року М. Джемілєва не впустили на територію Криму і заборонили в'їзд на півострів [10].

Станом на 2021 рік загалом у Російській Федерації і на тимчасово окупованих територіях півострова Крим i частин Донецької і Луганської областей незаконно утримуються 413 наших співгромадян за словами Уповноваженого Верховної Ради України з прав людини Людмили Денісової [11].

В окупованому Росією Криму найбільш жорстокі тортури щодо ув'язнених застосовують співробітники ФСБ, проте жодна справа щодо катувань до суду не потрапляє [12].

Тобто, на сьомий рік збройної агресії Росії впливові міжнародні організації систематично фріксують випадки жорстоко поводження та катування як із цивільним населенням так і з військовополоненими, затриманими та засудженими, що свідчить про нехтування державою-агресором своїми обов'язками як окупанта території, а саме, забезпечення дотримання прав людини та правопорядку.

Крім того, фріксуються тривожні випадки жорстокого поводження з боку Збройних сил України. Українська Гельсінська спілка з прав людини, неурядова організація "Truth Hounds" і ХПГ задокументували випадки затри- мання українськими силовиками 23 осіб на основі даних з 20 інтерв'ю, проведених з жертвами і свідками подій, а також переданих ними фотографій і документів. Усього 3 23 затриманих 19 стали жертвами тортур і жорстокого поводження. Серед задокументованих арештів лише в трьох випадках заарештовані брали участь у насильницьких діях, спрямованих на повалення української влади. В інших випадках заарештовані були колишніми учасниками ненасильницьких мітингів або цивільними, які не мали ніякого відношення до політичних подій [13].

Усе це створює катастрофічну ситуацію з дотриманням прав людини на тимчасово окупованих територіях.

Слід зазначити, що держава-окупант часто перешкоджає моніторингу дотримання прав людини міжнародними правозахисними організаціями на тимчасово окупованих територіях, що значно ускладнює процес реагування та запобігання вчиненню порушень.

Щорічно Європейський комітет із запобігання катуванню і нелюдському або такому, що принижує гідність, поводженню здійснює візити до України 3 метою перевірки умов тримання осіб, затриманих правоохоронними органами.

Також відвідують Україну та тимчасово окуповані території представники Комітету ООН проти катувань, зокрема, комісар ООН із протидії катуванням, спеціальний доповідач $\mathrm{OOH}$ із питань катувань.

Спеціальний доповідач ООН із питань катувань та інших жорстоких, нелюдських або таких, що принижують гідність, видів поводження Нільс Мельцер після двотижневого візиту до України 2018 р. стверджує про погані санітарні умови в місцях позбавлення волі, жорстоке поводження та катування затриманих у поліції, неможливість повного аналізу стану в'язниць на окупованих територіях [14].

Крім того, за результатами опрацювання доповіді Управління Верховного комісара $\mathrm{OOH}$ із прав людини "Щодо ситуації з правами людини в Україні" 2020 року Луганська обласна прокуратура розпочала кримінальне провадження за фактом жорстокого поводження з цивільним населенням, поєднаного з катуванням, з боку окупаційної адміністрації Російської Федерації (ч. 1 ст. 438 КК України). Грубі порушення норм міжнародного гуманітарного права у сфері захисту прав людини встановлено прокурорами управління нагляду у кримінальних провадженнях щодо злочинів, учинених на тимчасово окупованих територіях у Луганській області та в умовах збройного конфллікту [15].

Вказані злочинні дії прямо заборонені ст. 147 Женевської конвенції від 12 серпня 1949 року про захист цивільного населення під час війни та нормам міжнародного гуманітарного права щодо заборони насильства над цивільними особами.

Фактично система протидії агресії Росії політичними, юридичними й економічними засобами включає в себе запобігання катуванню та жорстокому поводженню. Так, важливим елементом протидії агресору стали спільні політикодипломатичні зусилля міжнародного співтовариства.

27 березня 2014 року Генеральна асамблея ООН схвалила Резолюцію 68/262 "Територіальна цілісність України", в якій підтвердила міжнародно визнані кордони України та відсутність будь-яких правових підстав для зміни статусу АР Крим та міста Севастополя [16]. Аналогічна позиція ГА ООН була підтверджена у Резолюції 71/205 "Ситуація з правами людини в АР Крим та місті Севастополь (Україна)", схваленій 19 грудня 2016 року. Окрім того, у Резолюції вперше в офріційних документах ООН Росія визнається державою-окупантом. Численні документи на підтримку територіальної цілісності України в межах міжнародно визнаних кордонів приймалися КМРЄ, ПАРЄ, ПА ОБСЄ тощо [2]. 
Крім того, 07 грудня 2020 року на 75-й сесії Генеральної Асамблеї ООН була схвалена Резолюція A/RES/75/29 "Проблема мілітаризації Автономної Республіки Крим та міста Севастополь (Україна), а також частин Чорного і Азовського морів", із засудженням окупації Росією українського Криму і її дій на захопленому півострові та закликом до консолідації зусиль світової спільноти з метою деокупації Криму [17]. У ній ідеться про незаконне захоплення Росією і встановлення нею контролю над колишніми об'єктами зберігання ядерної зброї у Криму і невпинну мілітаризацію півострова, про продовження призову жителів Криму до російських збройних сил на порушення міжнародного гуманітарного права чи про включення кримських освітніх навчальних закладів до російської "військово-патріотичної" системи освіти. Резолюція закликає Росію припинити таку практику. Прийняття резолюцій $є$ новим елементом дедалі більшого правового тиску на Росію та елементом запобігання катуванням.

Крім того, 13.03.2014 р. Уряд України подав до Європейського суду з прав людини міждержавну заяву проти Російської Федерації, враховуючи події, які почалися на території АР Крим 3 кінця лютого і тривають досі. Це зроблено з метою запобігти і не допустити подальших порушень прав осіб, які постійно проживають і тимчасово перебувають на території Кримського півострова, а також на території України загалом, з боку Російської Федерації, на підставі ст. 33 ("Міждержавні справи") Конвенції про захист прав людини і основоположних свобод 1950 р. У поданій міждержавній заяві й доповненнях до неї Україна вказує на порушення Росією прав, гарантованих ст. 2 ("Право на життя"), ст. 3 ("Заборона катування"), ст. 5 ("Право на свободу й особисту недоторканість"), ст. 8 ("Право на повагу до приватного і сімейного життя"), ст. 9 ("Свобода думки, совісті і релігії"), ст. 10 ("Свобода вираження поглядів"), ст. 11 ("Свобода зібрань та об'єднання"), ст. 14 ("Заборона дискримінації"), Європейської конвенції із захисту прав людини та основоположних свобод, ст. 1 Протоколу 1 ("Захист власності"), ст. 2 Протоколу 4 до Конвенції ("Свобода пересування") [18, с. 714]

На підтвердження позиції України було надано значний обсяг інформації щодо розвитку подій в АР Крим протягом лютого-березня 2014 року, уведення підрозділів збройних сил РФ на територію півострова та захоплення військових і цивільних об'єктів, а також свідчення 50 свідків щодо окупації РФ Кримського півострова та порушень прав людини у цей період (зокрема й осіб, які перебували в полоні так званої "самооборони Криму", та російських військових). Під час усних слухань щодо прийнятності цієї справи, які відбулися у вересні 2019 р., Європейський суд з прав людини також визнав прийнятними скарги України. Також Європейський суд 3 прав людини прийняв рішення приєднати до міждержавної справи "Україна проти Росії (щодо Криму)" за № 20958/14 міждержавну справу "Україна проти Росії" 38334/18 щодо політичних в'язнів. Наступний етап розвитку справи - розгляд скарги по суті [19].

19 лютого 2021 року Україною подано нову міждержавну заяву проти Російської Федерації щодо організації нею ряду резонансних замахів і замовних убивств, як на території України, так і на території держав-членів Ради Європи. Протягом тривалого часу Російською Федерацією широко застосовується тактика терору за допомогою політичних убивств на власній території і на території інших держав, а з початку агресії РФ та окупації частини нашої держави - і на території України. За період з 2014 року на території України було здійснено низку замахів та вбивств представниками спецслужб РФ, завербованими ними особами та представниками російських окупаційних адміністрацій "ЛНР" і "ДНР", які викликали значний резонанс в українському суспільстві. Причому Російською Федерацією не тільки не проводиться ефективне розслідування, а й вживаються заходи щодо перекладання відповідальності за такі злочини на інші держави, зокрема і на Україну. 22 лютого 2021 року ЄСПЛ повідомив Уряд України, що вказана міждержавна заява зареєстрована під № 10691/21 та відкрите провадження у цій справі [20]

Також важливо зазначити, що такі організації як Українська Гельсінська спілка з прав людини, Харківська правозахисна група, Amnesty International, ГО "Правозахисна група "Січ", "Форпост", Данський інститут із протидії катуванням DIGNITY, "Крим SOS" та інші в межах своєї експертної й адвокаційної діяльності активно перевіряють стан дотримання прав людини на тимчасово окупованих територіях. До прикладу, нині Україна завдяки вищезазначеним інституціям запроваджує Стамбульський протокол, який містить рекомендації для протидії катуванням і для доведення у судах фактів тортур, які вже мали місце. В Україні $€$ можливості документувати тілесні ушкодження відповідно до Стамбульського протоколу, але українське законодавство не повною мірою передбачає, що ці докази будуть враховані у суді.

Крім того, як зазначає Постійний представник Президента України в Автономній Республіці Крим Антон Кориневич підтримування зв'язків із громадянами АР Крим, постійне інформування, а також отримання українською стороною інформації стосовно стану дотримання прав людини на тимчасово окупованій території дає можливість для часткового запобігання таким порушенням, а також дозволить виконати майбутню реінтеграцію цих територій.

Крім того, на думку А. Кориневича потрібно прийняти закон про правовий статус політв'язнів, що значно підвищить гарантії захисту їхніх прав [21].

\section{ВИСНОВКИ}

Отже, як ми бачимо збройна агресія Росії щодо України створила катастрофрічні наслідки у вигляді зруйнованих людських життів, підірваної економіки, зруйнування всіх можливих демократичних інститутів. Постійний режим окупації відбувається із численними порушеннями не тільки міжнародного, а й гуманітарного права. Усе це створює безпрецедентні умови для свавілля незаконних військових угруповань на Сході України та збройних сил Росії на території Криму, що проявляються у скоєнні найтяжчих злочинів проти життя та людяності. У таких умовах вкрай важко, а подекуди неможливо запобігати катуванню та жорсткому поводженню. Протягом усього часу збройної агресії й окупації територій України безперервно фіксуються найважчі злочини, у тому числі катування та неналежне поводження. Запобігти катуванню у таких умовах майже неможливо, однак це не означає, що робота міжнародних місій, міжнародний правозахисних організацій має бути припинена. Навпаки, напрацювання вищезазначених органів створюють доказову базу для захисту прав потерпілих у національних і міжнародних судах.

Список використаних джерел

1. Задорожній О.В. Анексія Криму - міжнародний злочин. - К K.I.C., 2015. -572 c.

2. 10 фактів про збройну агресію Росії проти України. [Електронний pecypc]. - Режим доступу: https://mfa.gov.ua/10-faktiv-pro-zbrojnuagresiyu-rosiyi-proti-ukrayini

3. Задорожній О.В. Порушення агресивною війною Російської Федерації проти України основних принципів міжнародного права. - К. : K.I.C., 2015. - 712 c. 
4. Конвенція про закони і звичаї сухопутної війни від 18 жовтня 1907 року. [Електронний ресурс]. - Режим доступу: https://zakon.rada.gov.ua/ laws/show/995_222\#n124

5. Женевська конвенція про захист цивільного населення під час війни 1949 р. [Електронний ресурс]. - Режим доступу: https://zakon.rada.gov.ua/laws/show/995_154?find=1\&text=\%D0\%BE\%D0\% BA\%D1\%83\%D0\%BF\%D0\%B0\%D1\%86\#w1 1

6. Гаазька конвенція про захист культурних цінностей на випадок збройного конфлікту 1954 р. [Електронний ресурс]. - Режим доступу: https://zakon.rada.gov.ua/laws/show/995_157\#Text

7. Закон України "Про забезпечення прав і свобод громадян та правовий режим на тимчасово окупованій території України" від 15 квітня 2014 р. № 1207-VII. [Електронний ресурс]. - Режим доступу: https://zakon.rada.gov.ua/laws/show/1207-18\#Text

8. Задорожній О.В. Від теорії міжнародного права до захисту прав людини. Liber Amicorum до 60-річчя проф. B.B. Мицика: монографрія / О.В. Задорожній та О.Р. Поєдинок. - К., О.: Фенікс, 2016. - 718 с.

9. Закон України "Про особливий порядок місцевого самоврядування в окремих районах Донецької та Луганської областей" від 16 вересня 2014 року № 1680-VII. [Електронний ресурс]. - Режим доступу: https://zakon.rada.gov.ua/laws/show/1680-18\#Text

10. Дегтеренко А. Перспективи реінтеграції тимчасово окупованої території АР Крим шляхом забезпечення прав і свобод громадян України // "Гілея: науковий вісник". - Вип. 115. - с. 356-360.

11. Російська окупація: Денісова заявляє про незаконне утримання 413 українців. Укрінформ. [Електронний ресурс]. - Режим доступу: https://www.ukrinform.ua/rubric-society/3222445-rosijska-okupacia-denisovazaavlae-pro-nezakonne-utrimanna-413-ukrainciv.htm

12. Крим: Найбільш жорстокі тортури щодо ув'язнених застосовують співробітники ФСБ / Харківська правозахисна група. [Електронний ресурс]. - Режим доступу: http://khpg.org/1608808781

13. Ответственность за международные преступления, совершенные на востоке Украины в период 2014-2019 гг. / Харківська правозахисна група. [Електронний ресурс]. - Режим доступу: http://khpg.org/ 1579084118

14. Катування в поліції, погані умови у в'язницях, обмежений доступ на окуповані території: висновки спецдоповідача $\mathrm{OOH} з$ питань катувань. [Електронний ресурс]. - Режим доступу: https://zmina.info/news/ katuvannjia_zatrimanih_u_policiji_pogani_umovi_u_tiiurmah_obmezhenij_ dostup_na_okupovani_teritoriji_visnovki_specdopovidacha_oon_z_pitan_ katuvan/

15. Катування та жорстоке поводження з цивільним населенням на окупованій території Луганщини - прокуратура за доповіддю ООН розпочала кримінальне провадження / Луганська обласна прокуратура. [Електронний ресурс]. - Режим доступу: https://ug.gp.gov.ua/ua/ news.html? $m=$ publications\& $c=v i e w \& ~ t=r e c \& i d=281634$

16. Резолюція щодо територіальної цілісності України№ 68/262 від 27 березня 2014 року. [Електронний ресурс]. - Режим доступу: https://ips.ligazakon.net/document/MU14123

17. Резолюція "Проблема мілітаризації Автономної Республіки Крим та м. Севастополь (Україна), а також частин Чорного і Азовського морів" № A/RES/75/29 від 14 грудня 2020 року. [Електронний ресурс]. Режим доступу: https://undocs.org/ru/A/RES/75/29

18. Задорожній О.В. Міжнародне право в міждержавних відносинах України і Російської Федерації 1991 - 2014. - К. : К.І.С., 2014. - 960 с.

19. Денис Малюська: ЄСПЛ опублікував рішення щодо прийнятності справи "Україна проти Росії (Щодо Криму)". [Електронний ресурс]. Режим доступу: https://minjust.gov.ua/news/ministry/denis-malyuska-esplopublikuvav-rishennya-schodo-priynyatnosti-spravi-ukraina-proti-rosiischodo-krimu

20. Денис Малюська: Україна відкриває чергову ділянку юридичного фронту у протистоянні з Росією в ЄСПЛ. [Електронний ресурс]. - Режим доступу: https://minjust.gov.ua/news/ministry/denis-malyuska-ukraina-vidkrivaechergovu-dilyanku-yuridichnogo-frontu-u-protistoyanni-z-rosieyu-v-espl

21. Спецпроєкт "Здорова політика". Гість - представник Президента України в АР Крим Антон Кориневич. [Електронний ресурс]. - Режим доступу: https://www.youtube.com/watch?v=ymAyM1phG4o

\section{References}

1. Zadorozhniy O.V. (2015) Aneksia Krymu - mizhnarodnui zlochyn [The annexation of Crimea is an international crime]. Kyiv (in Ukrainian).

2. 10 factiv pro zbroinu agresiu proty Ukrainy [10 facts about Russia's armed aggression against Ukraine]. https://mfa.gov.ua/10-faktiv-pro-zbrojnuagresiyu-rosiyi-proti-ukrayini (in Ukrainian).

3. Zadorozhniy O.V. (2015) Porushenia agresyvnoiu viinoiu Rosiiskoi Federatsii proty Ukrainy osnovnuh prynstypiv mizhnarodnoho prava [Violation by the aggressive war of the Russian Federation against Ukraine of the basic principles of international law] (in Ukrainian).

4. Konvenstiia pro zakony suhoputnoi viiny [Convention on the Laws and Customs of War on Land]. https://zakon.rada.gov.ua/laws/show/ 995 222\#n124 (in Ukrainian).

5. Zhenevska konvenstiia pro zahyst styvilnoho naselenia [Geneva Convention relative to the Protection of Civilian Persons in Time of War]. https://zakon.rada.gov.ua/laws/show/995_154?find=1\&text=\%D0\%BE\%D0\% BA\%D1\%83\%D0\%BF\%D0\%B0\%D1\%86 \# w1_1 (in Ukrainian).
6. Haahska konvenstiia pro zahyst kylturnyh stinnostei na vypadok zbroinoho konflilty [Hague Convention for the Protection of Cultural Property in the Event of Armed Conflict]. https://zakon.rada.gov.ua/laws/show/ 995_157\#Text (in Ukrainian).

7. Pro zabeapechenia prav i svobod hromadian ta pravovyi regym na tymchasovo okypovanii terytoii Ukrainy, Zakon Ukrainy [On Ensuring the Rights and Freedoms of Citizens and the Legal Regime in the Temporarily Occupied Territory of Ukraine, Law of Ukraine] https://zakon.rada.gov.ua/ laws/show/1207-18\#Text (in Ukrainian).

8. Zadorozhniy O.V. (2016) Vid teorii mizhnarodnoho prava do zahystu prav liudyny [From the theory of international law to the protection of human rights] (in Ukrainian).

9. Pro osobluvui poriadok mistevoho samovriaduvania $v$ okremyh raionah Donestkoi ta Luhanskoi oblastei, Zakon Ukrainy [On the special order of local self-government in certain districts of Donetsk and Luhansk regions: Law of Ukraine] https://zakon.rada.gov.ua/laws/show/1680-18\#Text (in Ukrainian).

10. Degterenko A. Perspektyvy reintegrastii tymchasovo okupovanoi terytorii AR Krym shliahom zabezpechennia prav i svobod hromadian Ukrainy / Hileia: naykovyi visnyk. Vypusk 115 [Prospects for reintegration of the temporarily occupied territory of the Autonomous Republic of Crimea by ensuring the rights and freedoms of citizens of Ukraine]. Gilea: a scientific journal. Issue 115. (in Ukrainian).

11. Rosiys'ka okupatsiya: Denisova zayavlyaye pro nezakonne utrymannya 413 ukrayintsiv. Ukrinform [Russian occupation: Denisova claims illegal detention of 413 Ukrainians. Ukrinform] https://www.ukrinform.ua/ rubric-society/3222445-rosijska-okupacia-denisova-zaavlae-pro-nezakonneutrimanna-413-ukrainciv.html (in Ukrainian)

12. Krym: Naybil'sh zhorstoki tortury shchodo uv"yaznenykh zastosovuyut' spivrobitnyky FSB / Kharkivs'ka pravozakhysna hrupa [Crimea: The most brutal torture of prisoners is used by FSB officers. Kharkiv Human Rights Group] http://khpg.org/1608808781 (in Ukrainian).

13. Otvetstvennost' za mezhdunarodnye prestuplenyya, sovershennye na vostoke Ukrayny v peryod 2014-2019 hh. / Kharkivs'ka pravozakhysna hrupa. [Responsibility for international crimes committed in eastern Ukraine in the period 2014-2019. Kharkiv Human Rights Group] http://khpg.org/ 1579084118 (in Ukrainian).

14. Katuvannya $v$ politsiyi, pohani umovy u v'yaznytsyakh, obmezhenyy dostup na okupovani terytoriyi: vysnovky spetsdopovidacha OON z pytan' katuvan'. [Torture in the police, poor conditions in prisons, limited access to the occupied territories: conclusions of the UN Special Rapporteur on Torture] https://zmina.info/news/katuvannjia zatrimanih u policiji pogani umovi u_tjiurmah_obmezhenij_dostup_na_okupovani_teritoriji_visnovki_specdopo vidacha_oon_z_pitan_katuvan/ (in Ūkrainian).

15. Katuvannya ta zhorstoke povodzhennya $z$ tsyvil'nym naselennyam na okupovaniy terytoriyi Luhanshchyny - prokuratura za dopoviddyu OON rozpochala kryminal'ne provadzhennya / Luhans'ka oblasna prokuratura. [Torture and ill-treatment of civilians in the occupied territory of Luhansk region - the prosecutor's office on the basis of a UN report initiated criminal proceedings / Luhansk Regional Prosecutor's Office] https://lug.gp.gov.ua/ ua/news.html? $m=$ publications\& $c=v i e w \& ~ t=r e c \& i d=281634$ (in Ukrainian).

16. Rezolyutsiya shchodo terytorial'noyi tsilisnosti Ukrayiny№ 68/262 vid 27 bereznya 2014 roku. [Resolution on the Territorial Integrity of Ukraine № 68/262 of 27 March 2014] https://ips.ligazakon.net/document/MU14123 (in Ukrainian).

17. Rezolyutsiya "Problema militaryzatsiyi Avtonomnoyi Respubliky Krym ta m. Sevastopol' (Ukrayina), a takozh chastyn Chornoho i Azovs'koho moriv" № A/RES/75/29 vid 14 hrudnya 2020 roku. [Resolution "The problem of militarization of the Autonomous Republic of Crimea and the city of Sevastopol (Ukraine), as well as parts of the Black and Azov Seas" № A / RES / 75/29 of 14 December 2020] https://undocs.org/ru/A/RES/75/29 (in Ukrainian).

18. Zadorozhniy O.V. Mizhnarodne pravo v mizhderzhavnykh vidnosynakh Ukrayiny i Rosiys'koyi Federatsiyi 1991 - 2014. (2014) [International law in interstate relations between Ukraine and the Russian Federation 1991 - 2014]. (in Ukrainian).

19. Denys Malyus'ka: YESPL opublikuvav rishennya shchodo pryynyatnosti spravy "Ukrayina proty Rosiyi (Shchodo Krymu)". [The ECtHR has published a decision on the admissibility of Ukraine v. Russia (Concerning Crimea)]. https://minjust.gov.ua/news/ministry/denis-malyuska-esplopublikuvav-rishennya-schodo-priynyatnosti-spravi-ukraina-proti-rosiischodo-krimu(in Ukrainian).

20. Denys Malyus'ka: Ukrayina vidkryvaye cherhovu dilyanku yurydychnoho frontu u protystoyanni z Rosiyeyu v YESPL. [Ukraine opens another section of the legal front in the confrontation with Russia in the ECHR]. https://minjust.gov.ua/news/ministry/denis-malyuska-ukraina-vidkrivaechergovu-dilyanku-yuridichnogo-frontu-u-protistoyanni-z-rosieyu-v-espl (in Ukrainian).

21. Spetsproyekt "Zdorova polityka". Hist' - predstavnyk Prezydenta Ukrayiny v AR Krym Anton Korynevych. [Special project "Healthy Policy". The guest is Anton Korynevych, the representative of the President of Ukraine in the Autonomous Republic of Crimea]. https://www.youtube.com/ watch?v=ymAyM1phG4o (in Ukrainian). 
Kh. Yamelska, PhD Student

Taras Shevchenko National University of Kyiv, Kyiv, Ukraine

\section{PREVENTION OF TORTURE ON THE TEMPORARILY OCCUPIED TERRITORIES OF UKRAINE}

The article reveals the content of armed aggression and the legal status of the temporarily occupied territories of Ukraine. Russia's aggression against Ukraine is considered in historical retrospect. Cases of torture and other ill-treatment on the temporarily occupied territories have been demonstrated in specific cases. The article examines the state of human rights on the temporarily occupied territories, namely the prevention of torture and other ill-treatment. Ways to prevent torture and ill-treatment in order to respect human rights and maintain the rule of law have been identified.

The author determined that system of counteraction to aggression of Russia, which consists the political, legal and economic means, includes the prevention of torture and ill-treatment.The author notes that the adoption of UN GA resolutions and other documents of the Committee of Ministers of the Council of Europe, the Parliamentary Assembly of the Council of Europe, the Organization for Security and Co-operation in Europe are new elements of increasing legal pressure on Russia. The submission of interstate applications by the Government of Ukraine to the European Court of Human Rights against the Russian Federation is one of the effective means of preventing torture.

The article reveals the impact of expert and advocacy activities of non-governmental human rights organizations on the prevention of torture and the state of human rights on the temporarily occupied territories.

It is noted that maintaining contacts with the citizens of the Autonomous Republic of Crimea, constant informing, as well as obtaining information by the Ukrainian side on the state of human rights in the temporarily occupied territory provides an opportunity to partially prevent such violations and allow future reintegration of these territories.

Keywords: prevention of torture, temporarily occupied territories, armed aggression, observance of human rights. 